\title{
PENGGUNAAN GAYA BAHASA METAFORA DALAM BUKU KIKE WADATSUMI NO KOE
}

\author{
Subandi \\ FakultasBahasadanSeni, Unesa \\ (banjuchi69@yahoo.co.jp) \\ Lies Tyan Diniswari \\ (liestyan444@gmail.com)
}

\begin{abstract}
Abstrak
Gaya bahasa metafora yang memiliki konsep makna dasar perbandingan sebagai konskuensi dari pemilihan kata/diksi dapat menjadikan sebuah ungkapanlepas dari makna unsur pembentuknya. Proses perbandingan mengakibatkan terjadinya perpindahan makna satu kata ke kata yang lain yang didasari oleh adanya kesamaan baik secara konseptual maupun fisik. Akibatnya struktur luar gaya bahasa metafora dibangun oleh subyek yang sebenarnya berfungsi sebagai pembanding dan berada di luar scopp makna yang diwakilinya. Sebaliknya subyek yang dibandingkan yang sebenarnya berfungsi sebagai makna inti ungkapan tidak muncul dalam struktur luarnya tetapi, membangun struktur makna dimana struktur makna ini ada dalam konsep mental setiap penutur. Terbangunnya struktur makna pada gaya bahasa metafora dapat diakibatkan oleh terjalinnya kesamaan konsep aspek fungsi, keadaan, fisik, karakter dan yang lainnya diantara subyek pembanding dan subyek yang dibandingkan. Penggunaan gaya bahasa metafora dalam komunikasi tentu dilandasi oleh suatu motivasi dan tujuan tertentu namun demikian, dengan gaya bahasa metafora penutur mampu mengungkapkan makna yang melebihi dari makna yang terkandung dalam struktur luarnya. Lebih dari itu, dengan penggunaan gaya bahasa akan menghasilkan bentuk komunikasi dengan varian pilihan kata yang bervariasi sehingga, mampu meningkatkan kualitas aktivitas berbahasa.
\end{abstract}

Kata Kunci: Struktur makna, struktur luar, struktur dalam, mental konsep

\section{A. PENDAHULUAN}

Penggunaan bahasa dalam aktivitas komunikan masing-masing memiliki cara dan gaya sendiri-sendiri dimana gaya tersebut pada akhirnya menjadi penciri khusus kepada penuturnya. Gaya berbahasa seorang penutur dapat ditandai dengan adanya penggunaan bentuk bahasa, pilihan kata/diksi, intonasi sampai pada penggunaan gaya bahasa atau majas. Sangat menarik manakala gaya bahasa dilibatkan sebagai media untuk menyampaikan gagasan dan pikiran dalam aktivitas berkomunikasi. Hal ini dikarenakan, gaya bahasa memiliki keterikatan dengan beberapa prosedur dan prasyarat tertentu yang berakibat pada terbatasnya jangkauan ketersampaian maknanya akibat tidak setiap peserta komunikasi 
mampu memahami makna dan maksud gaya bahasa tersebut tetapi, gaya bahasa masih mampu memikat simpatik penggunanya. Keterbatasan pengetahuan tentang penggunaan dan pemahaman terhadap makna gaya bahasa memang akan menjadikan penghambat proses berkomunikasi tetapi, kondisi sebaliknya akan mampu mengangkat aktivitas komunikasi ke titik yang lebih berkualitas dan menempatkan pada posisi tingkat komunikasi yang lebih tinggi. Gaya bahasa mampu memberikan informasi yang melebihi makna unsur pembentuknya karena, gaya bahasa memiliki kandungan makna efek yang tidak muncul ke permukaan struktur rielnya.

Sering dikatakan bahwa penggunaan gaya bahasa lebih sering ditujukan untuk menperoleh aspek estetika, meskipun pernyataan ini tidak salah tetapi sebenarnya, penggunaan gaya bahasa juga ditujukan untuk menyampaikan informasi lain yang tidak dinyatakan secara eksplisit disaat penutur memutuskan untuk tidak menyampaikan informasi tersebut secara langsung dan fulgar, akibat alasan tertentu yang menyebabkan penutur lebih memilih menyampaikan melalui gaya bahasa yang digunakan. Seperti yang dinyatakan oleh Ratna (2009:164) bahwa, penggunaan gaya bahasa digunakan agar memperoleh aspek keindahan. Gaya bahasa selain berfungsi untuk memperoleh aspek estetika sebenarnya juga memiliki kemampuan untuk menyampaikan pikiran penutur tanpa harus mengangkat keluar konsep pikiran tersebut ke permukaan bentuk tuturan.

Terbentuknya konsep makna gaya bahasa salah satunya hasil dari proses perbandingan yaitu, membandingkan obyek yang satu dengan obyek yang lain dengan didasari oleh adanya aspek kesamaan dan atau kimiripan yang dimiliki oleh kedua obyek tersebut. Dalam kasus seperti ini, obyek yang satu berperan sebagai pembanding sedangkan obyek yang lain berfungsi sebagai yang dibandingkan. Gaya bahasa perbandingan sering digunakan baik dalam komunikasi lisan maupun komunikasi tulis karena, dianggap proses penyampaian maknanya terbantu oleh obyek lain yang berperan sebagai pembanding sehingga, sangat membantu proses pemahaman oleh lawan bicara. Salah satu bentuk gaya bahasa perbandingan yang frekuensi penggunaannya cukup tinggi yaitu, gaya bahasa metafora. Gaya bahasa metafora ini memiliki keunikan tersendiri yaitu, tidak digunakannya kata penanda perbandingan secara langsung sehingga, dapat 
mengakibatkan peserta tutur merasa tidak menyadari akan munculnya bentuk ungkapan metafora karena, akibat tidak munculnya tanda pembanding secara langsung sangat memungkinkan peserta tutur menganggap sebagai bentuk tuturan biasa. Oleh karena itu,jika hanya melihat dari bentuk struktur luarnya saja, khususnya bagi lawan tutur yang kurang memahami tentang aspekpenanda metafora maka, bisa saja lawan bicara akan tidak menyadari terhadap kemunculan gaya bahasa metafora yang digunakan oleh penutur selama proses komunikasi berlangsung. Jika hal seperti ini terjadi, maka akibatnya proses komunikasi akan tidak lancar atau yang lebih fatal lagi dapat menyebabkan putusnya proses komunikasi sehingga, tujuan komunikasi tidak dapat tercapai. Namun sebaliknya, jika peserta tutur saling memahami terhadap konsep metafora maka, kondisi tersebut akan dapat membantu memaksimalkan proses komunikasi dan yang lebih lagi sangat dimungkinkan munculnya informasi tambahan yang melebihi informasi unsur pembentuk struktur luarnya. Hal ini disebabkan, informasi tambahan yang dimaksud tidak turut menyertai di dalam struktur lahir dari metafora tersebut, informasi tambahantersebut tersembunyi di dalam konsep makna metafora yang berfungsi sebagai struktur dalam metafora. Sebagai contoh dapat diperhatikan penggalan kalimat yang dikutip dari buku Kike Wadatsumi no Koe.

1). Boku wa ningen ga oitsumerareru to kemono ya kikai ni naru toiu koto o kangaeru node aru ga......"

"Saya pikir jika manusia dalam keadaan terpepet maka akan menjadibinatang buasdan mesin”(K.h.7. b. $1^{1}$ ).

Pada kutipan di atas terdapat dua bentuk metafora yang digunakan yaitu, kata /kemono/ (binatang buas) dan kata /kikai/ (mesin) dimana kedua kata tersebut berperan sebagai struktur luar yang berfungsi menyampaikan makna tersurat. Sementara itu, secara keseluruhan kutipan 1) di atas tidak hanya mengungkapkan makna tersuratnya lebih dari itu, makna tersirat justru menjadi tujuan utama yang hendak disampaikan. Yaitu sifat-sifat seperti yang dimiliki oleh /kemono/ (binatang buas) misalnya hati nurani sudah tidak berfungsi, berbuat liar bahkan ${ }^{1} \mathrm{~K}$ : Judul Buku “Kike Wadatsumi no Koe", h: halaman, b: baris. 
menyerang secara membabi buta dan sejenisnya, serta karakter /kikai/ (mesin) seperti misalnya logika sudah tidak berfungsi, bergerak dan bertindak berdasarkan instruksi serta kendali dan sejenisnya digunakan untuk menggambarkan karakter dan sifat manusia di saat dalam keadaan terpaksa dan terdesak oleh situasi dan kondisi. Pemahaman seperti ini membuktikan bahwa unsur-unsur bahasa yang membentuk konstruksi fisik sebuah tuturan tidak menjadi tujuan utama dalam sebuah tindak komunikasi tetapi hanya berperan sebagai penghantar untuk menyampaikan makna inti yang menjadi tujuan utama kepada lawan bicara.

\section{Gaya Bahasa Metafora}

Berbicara tentang gaya bahasa nampaknya lebih identik dengan aspek estetika yaitu, aspek keindahan yang dimiliki oleh suatubentuk ungkapan. Walaupun pada kenyataannya bahwa, gaya bahasa tidak hanya berhubungan dengan aspek keindahan saja, setidaknya gaya bahasa menjadi salah satu cara tersendiri dan khas yang digunakan oleh penutur guna memperoleh makna yang melebihi dari makna lahirnya. Sementara itu Ratna menyampaikan bahwa gaya bahasa merupakan keseluruhan cara yang dilakukan saat menggunakan bahasa (2009: 29). Artinya bahwa, gaya bahasa berperan sebagai cara, teknik, dan atau strategi yang digunakan oleh penutur guna mencapai tujuan komunikasi secara maksimal.Didukungoleh pendapat Sumardjo dan Saini menyebutkan bahwa, gaya bahasa merupakan alat berbahasa agar daya ungkap atau daya tarik atau keduanya bisa bertambah (1986: 127-128). Dengan demikian, penggunaan gaya bahasa sebetulnya juga tidak lepas dari adanya upaya untuk mencapai tujuan komunikasi secara maksimal oleh peserta tutur yang dibebankan terhadap penggunaan gaya bahasa.

Gaya bahasa metafora sebagai salah satu bentuk gaya bahasa perbandingan memiliki frekuensi penggunaan yang cukup tinggi. Hal ini didukung oleh pendapat Yamanashi (1988:13) secara konseptual menyebutkan bahwa, majas perbandingan tidak hanya ada di dalam bahasa seni atau sastra saja karena, gaya bahasa perbandingan ini juga diterima sebagaibentuk kata yang hidup di dalam variasi bentuk ungkapan sehari-hari. Selanjutnya Ratna juga menyampaika bahwa, gaya bahasa perbandingan merupakan salah satu gaya bahasa yang sering 
digunakan (2009:164). Penggunaan gaya bahasa perbandingan khususnya gaya bahasa metafora meskipun dari sisi bentuk tidak dapat dilepaskan dari aspek keindahan namun demikian, penggunaan gaya metafora tidak hanya terbatas pada dunia seni dan atau sastra saja tetapi, di dalam bentuk kehidupan sehari-hari juga sering digunakan.

Sehubungan dengan konsep perbandingan, Tarigan menyampaikan bahwa gaya bahasa perbandingan digunakan untuk meningkatkan efek dengan jalan memperkenalkan serta membandingkan suatu benda atau hal tertentu dengan benda lain secara umum (1990:179). Dari konsep tersebut yang menjadi penekanan pada gaya bahasa perbandingan yaitu, adanya dua obyek yang satu berperan sebagai pembanding dan yang lainnya berfungsi sebagai yang dibandingkan. Sementara itu terkait gaya bahasa metafora Parera mendefinisikan, salah satu solusi untuk melayani pikiran dan perasaan pemakai bahasa yaitu, sumber untuk melayani motivasi yang kuat, untuk menyatakan perasaan dan sarana berbahasa yang bersifat penting (2004:119). Devinisi Parera belum secara eksplisit menyajikan konsep utama sebagai penanda gaya bahasa metofora, akan tetapi dalam definisi tersebut telah disebutkan "sumber untuk melayani motivasi yang kuat" dari batasan ini telah ditekankan bahwa penggunaan gaya bahasa metafora akibat adanya dorongan/keinginan pada diri penutur dengan alasan dan tujuan tertentu untuk menyampaikan makna tuturan melalui obyek lain tidak secara eksplisit. Sedangkan menurut Ungerer dan Hans (1996:142) menyebutkan, metafora adalah ungkapan yang secara turun-temurun dan terbentuk oleh dasar "persamaan" dan atau "perbandingan" antara makna sebenarnya dari sebuah ungkapan dengan makna perbandingannya. Sejalan dengan Ungerer, Takiura (1988:89) juga menggaris bawahi bahwa gaya bahasa metafora memiliki karakteristik yang ditandai oleh adanya proses perpindahan dari tempat yang satu ke tempat yang lain, dalam retorika berarti berpindahnya makna kata/bahasa yang satu ke makna kata/bahasa yang lain. Pendapat Ungerer dan Takiura memberikan tawaran kosep yang lebih jelas sehingga kedua pendapat tersebut dapat disejajarkan dengan menggabungkan inti dari konsep yang ditawarkan yaitu, berpindahnya makna suatu ungkapan ke bentuk ungkapan yang lain akibat adanya aspek kesamaan atau kemiripan sebagai hasil dari proses perbandingan. 
Metafora memiliki ciri khusus dimana ciri ini tidak dimiliki oleh jenis gaya bahasa perbandingan yaitu, tidak hadirnya unsur penanda pembanding secara langsung seperti kata 'seperti', 'bagaikan', 'laksana' dan sejenisnya. Nakamura (1985:36) juga menyampaikan bahwa, metafora memiliki ciri khusus yaitu tidak memakai kata perumpamaan dalam pemakaiannya. Sejalan dengan Nakamura, Sutedi (2008:193) juga menambahkan bahwa untuk membedakan dengan simile, metafora tidak menggunakan kata 'seperti' atau 'bagaikan'. Penerapan konsepkonsep tersebut di atas dapat dilihat pada contoh berikut yang dikutip dari Seto (1997:38).

2). Otoko wa okami de aruda.

(Laki-laki itu serigala).

Bentuk ungkapan 2) di atas, sering digunakan oleh penutur perempuan dalam konteks korban hubungan asmara dimana pihak wanita menjadi korban tipu muslihat laki-laki. Kata lokamil (serigala) pada contoh 2) di atas kata yang dipinjam untuk digunakan sebagai pembanding guna menggantikan obyek lain yaitu, /otoko/ (laki-laki) yang memiliki karakteristik seperti lokami/ (serigala). Dalam pandangan budaya masyarakat Jepang, binatang lokamil (serigala) ditempatkan sebagai binatang yang memiliki karakteristik buas, sadis, dan suka mencuri kesempatan. Objek lotoko/ (laki-laki) adalah kata yang merujuk pada manusia tepatnya, orang laki-laki. Dalam urusan asmara laki-laki lebih sering berbuat curang, dengan segalan kebohongannya berbuat apa saja untuk mengelabuhi wanita untuk mendapatkan apa yang diinginkan dari wanita. Tetapi jika sudah tercapai apa yang diinginkan, tidak jarang laki-laki berbuat sekehendaknya mulai dari berpura-pura, berbohong hingga meninggalkannya. Gambaran perilaku dan karakter seorang laki-laki seperti ini yang digunakan sebagai dasar untuk menempatkan kata /okami/ (serigala) sebagai pilihan kata yang dianggap dapat mewakili konsep pemikiran dan gagasan untuk mengungkapkan makna informasi tambahan berupa informasi kesamaan karakter kebuasan dan kesadisan yang dimiliki oleh seekor srigala. 


\section{Makna Metafora}

Memahami makna suatu bahasa menduduki hierarki yang penting karena, pemahaman terhadap makna bahasa menjadi syarat paling utama dalam sebuah komunikasi. Ketidak pahaman terhadap makna bahasa sudah dapat dipastikan tidak akan terjadi proses komunikasi karena proses penyampaian informasi tidak dapat terlaksana sehingga tujuan tindak komunikasi akan menjadi gagal. Makna sebuah bahasa menjadi ruh utama yang akan menjadi penggerak utama dari fungsi dan peranan sebuah bahasa dalam tindak komunikasi. Hal ini didukung oleh pendapat Keraf yang menyebutkan, makna yang terbentuk dari kata atau rangkaian kata-kata seperti 'jiwa' (2010:21). Artinya, makna bahasa sebagai 'jiwa' menjadi sumber dan kendali utama setiap kehidupan berbahasa. Makna begitu pentingnya dalam dunia bahasa terutama bahasa yang telah difungsikan peranannya dalam sebuah komunikasi.

Makna bahasa tidak selamanya terikat dan tunduk pada kaidah gramatikal dan sistem leksikal. Hal ini dikarenakan, kedua aturan tersebut masih belum dapat memenuhi tuntutan gagasan-gagasan manusia yang sangat komplek dan tak terbatas. Perkembangan peradapan mengakibatkan terjadinya perubahan sistem dan konsep dari sebuah budaya yang dapat pula mengakibatkan terjadinya pergeseran bahkan perubahan makna sebuah ungkapan bahasa, sehingga memunculkan makna baru seiring dengan munculnya gagasan-gagasan baru penuturnya. Djadjasudarma menyampaikan, makna sebuah kalimat yang baik ialah kalimat yang pilihan kata dan susunan gramatikalnya sering tidak dipahami tanpa memperhatikan hubungan dengan kalimat lain (1999:6). Artinya, makna yang menyimpang dari makna leksikal atau makna yang menimbulkan gagasan baru, keberadaannya dianggap lebih menarik karena dianggap sebagai sarana baru untuk mengungkapkan informasi makna baru yang berlawanan dan atau menyimpang dengan makna leksikal dimana, karakter seperti ini lebih dimiliki oleh bentuk ungkapan metafora.

Untuk memahami makna ungkapan metafora sekiranya perlu memperhatikan dua hal yaitu, ide yang mendasari pembentukan metafora yang satu adalah kenyataan yaitu sesuatu yang dipikirkan dan berfungsi sebagai obyek, dan satu 
lagi sebagai perbandinganterhadap kenyataan tadi. Hal ini sesuai dengan pendapat Seto (1997:39) yang secara garis besar menyatakan bahwa, makna metafora dipahami melalui hubungan antara 'contoh' dengan 'yang dicontohkan'. Contoh merupakan subyek pembanding sedangkan yang dicontohkan merupakan subyek yang diperbandingkan. Baik pembanding maupun yang diperbandingkan masingmasing memiliki konsep dan diantara konsep tersebut terdapat aspek kesamaan yang berfungsi sebagai penghubung keduanya. Kesamaan konsep tersebut oleh Subandi (2000:198) digambarkan dengan bentuk segita tiga hubungan makna seperti berikut.

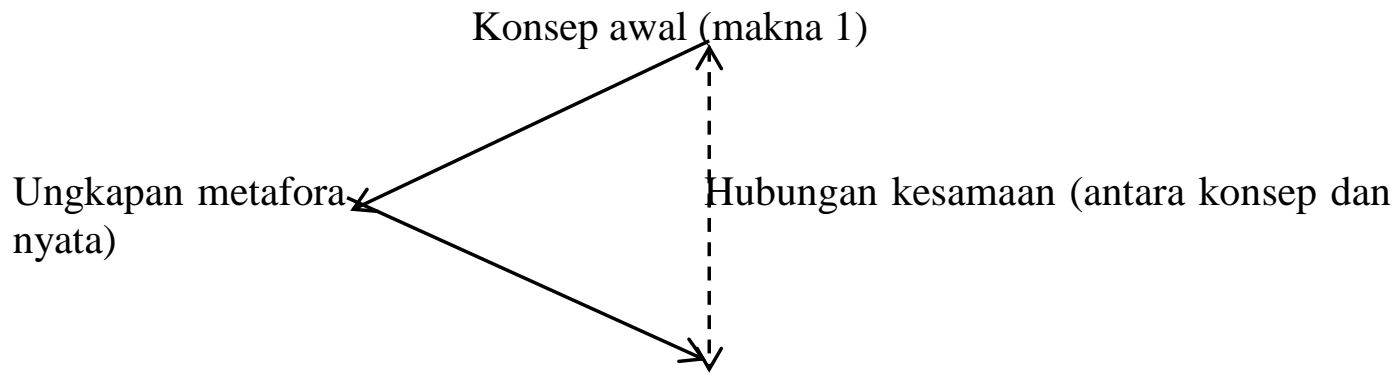

Subyek nyata dengan konsep baru (makna 2)

Bagan 1. Segitiga hubungan makna

Bagan di atas dapat dipahami seperti berikut. Makna 1 merupakan konsep awal atau makna leksikal dari subyek pembanding, yaitu subyek yang dijadikan perbandingan. Subyek ini masih berupa konsep belum nyata, artinya masih berada dalam tahap pemikiran penutur sehingga, masih sangat abstrak. Untuk lebih mengkongkritkan konsep yang masih abstrak tersebut ditungkan dalam bentuk tuturan yang berwujud ungkapan metafora. Dari ungkapan metafora inilah konsep awal yang masih bersifat abstrak menjadi lebih kongkrit dibandingkan dengan makna 1. Secara mental, sebenarnya pada tahap realisasi makna 1 ke ungkapan metafora ini sudah terjadi proses pergeseran makna akibat proses perbandingan. Hal ini dikarenakan, secara semantis bentuk ungkapan yang digunakan dengan konsep makna 1 tidak memiliki keterkaitan secara langsung, keterkaitan itu terjadi semata akibat dari proses perbandingan, pada bagan di atas ditunjukkan dengan garis putus-putus. Sehingga, ungkapan yang semula memiliki konsep makna awal dengan makna 1 berubah menjadi makna 2 dengan konsep baru, dimana konsep 
baru ini sebenarnya merupakan konsep awal dari subyek yang dijadikan pembanding. Akibatnya, subyek nyata tersebut memiliki konsep makna baru. Implementasi peta konsep seperti pada bagan di atas dapat dilihat pada contoh yang dikutip dari Seto (1997:23) berikut.

\section{3). Chichi oya wa daikokubashira o se ni site suwatta.}

(Ayah duduk sebagai tiang penyangga.)

Kata /daikokubashiral (tiang penyangga) sebenarnya merujuk pada makna tiang utama pada konstruksi rumah yang memiliki fungsi utama menyangga bagian-bagian pokok rumah tetapi, dalam konteks seperti pada contoh 3) di atas, konsep makna kata /daikokubashira/ (tiang penyangga) digunakan sebagai acuan atau dasar proses perbandingan guna merujuk pada seorang ayah yang memiliki tugas sebagai penopang utama atau seorang ayah yang memberi sumber kehidupan utama untuk menjaga keberlangsungan kehidupan suatu keluarga. Konsep fungsi utama tiang penyangga untuk menjaga agar bangunan rumah tetap dapat berdiri dan kokoh sedangkan, konsep peranan seorang ayah yang menjadi penyangga utama dari beban dan keberlangsungan hidup suatu keluarga agar kehidupan keluarga tetap dapat berlangsung disejajarkan guna memperoleh konsep baru yaitu, konsep awal peranan utama seorang ayah dalam keluarga yang dirujuk dengan bentuk ungkapan metafora /daikokubashiral (tiang penyangga). Sehingga jika digambarkan dengan bagan segita makna Ogden dan Richard, seperti yang disarikan oleh Subandi (2000: 199) menjadi seperti bagan 2 berikut.

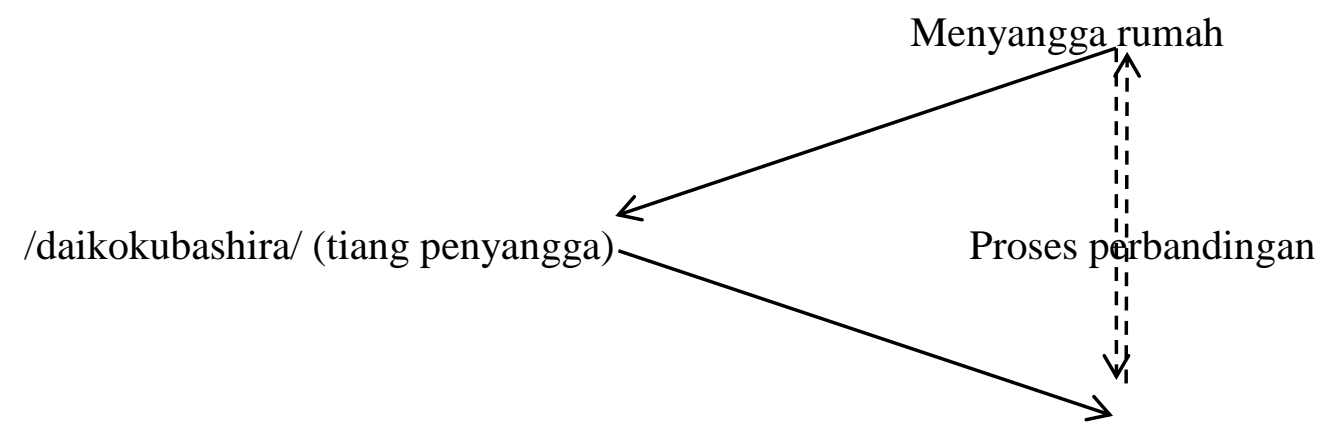

Menyangga rumah tangga 


\section{Fungsi Metafora}

Untuk dapat memahami makna metafora, juga dianggap penting mengetahui fungsi metafora. Hal ini dikarenakan fungsi metafora menentukan makna sebuah ungkapan metafora. Apakah suatu bentuk ungkapan metafora tersebut memiliki makna metafora yang baru yaitu, makna yang memiliki ketergantungan terhadap konteks tuturan atau, hanya mengungkapkan satu makna tertentu yaitu, makna tetap yang tidak terpengaruh oleh perbedaan konteks. Berdasarkan fungsinya Seto (1995: 21) membagi ungkapan metafora menjadi dua jenis yaitu, metafora hidup dan metafora mati. Yang dimaksud metafora hidup yaitu, bentuk ungkapan yang alami dan maknanya mampu membangkitkan berbagai macam imajinasi. Artinya, makna yang dihasilkan oleh ungkapan metafora hidup dapat menimbulkan makna atau gagasan baru. Maknanya berubah mengikuti waktu dan konteks yang melatarbelakangi. Perubahan makna akibat perbedaan konteks yang dimiliki ini, dianggap sebagai bentuk kehidupan ungkapan metafora. Sebagai contoh dapat diperhatikan kutipan berikut yang dikutip dari Watanabe (www.tku.ac.jp/kiyou/contens. diakses 2012/06/20).

4). Kare wa denshin bashira da.

(Lelaki itu adalah tiang telepon).

Makna kata /denshin/ (tiang listrik) pada contoh 4) di atas tidak merujuk pada obyek tiang yang berfungsi sebagai penyangga kabel aliran listrik sebagai makna 1 tetapi, akibat dari konteks tuturan, kata tersebut lebih merujuk pada makna metafora yaitu, lelaki yang memiliki postur tubuh kecil, langsing dan tinggi yang mirip dengan keadaan fisik tiang listrik sebagai makna 2. Makna 2 ini akan hilang mana kala konteks tuturan berubah seperti pada contoh bentuk tuturan5) berikut.

\section{5). Kare wa denshin bashira de kanojo o matte imasu.}

(Lelaki itu menunggu gadis itu di bawah tiang listrik).

Kata /denshin bashiral (tiang listrik) sama-sama muncul pada contoh 4) dan 5) tetapi, karena keduanya memiliki konteks yang berbeda akibatnya, makna keduanya juga menjadi berbeda. Makna pada contoh 5) sudah pasti dan jelas merujuk pada makna 1. Sehingga kata /denshin bashiral (tiang listrik) pada 
contoh 4) tidak dapat mengemban peran dan fungsi seperti pada contoh 5). Dengan karakteristik makna yang dimiliki oleh kata /denshin bashiral (tiang listrik) seperti ini maka, jenis makna yang dimiliki masuk jenis metafora hidup.

Jenis metafora yang kedua yaitu jenis metafora mati. Masih menurut Seto (1995:21) bahwa yang dimaksud metafora mati ialah, daya makna awal yang dimiliki oleh unsur pembentuknya memudar selanjutnyamembentuk suatu daya makna baru dan tersebut berperan sebagai rujukan dalam ungkapan sehari-hari. Artinya, karakteristik makna metafora mati tidak akan mengalami perubahan sebagai akibat dari berubahnya konteks tuturan, tetapi makna tersebut telah mengkristal secara tetap meskipun berada dalam berbagai bentuk dan jenis konteks tuturan. Kemungkinan munculnya konsep makna baru pada jenis metafora mati sudah tertutup karena, bentuk tersebut sudah menjadi bentuk ungkapan yang tetap dan sudah digunakan sebagai ungkapan dalam kehidupan sehari-hari. Sehingga jenis makna metafora ini sudah bergeser mendekati jenis ungkapan idiom karena, makna leksikal yang dimiliki oleh unsur pembentuknya sudah hilang. Makna tetap yang dirujuk oleh metafora mati sudah tidak dapat ditelusuri lagi jika hanya melibatkan makna unsur bembentuknya saja tetapi, harus melibatkan unsur lain yang ada di luar unsur pembentuk struktur luarnya. Sebagai contoh, kata /me/ (mata) pada frase 'hari no $\underline{m e}$ ' (mata jarum) masuk jenis metafora mati karena, bagaimanapun konteks yang melatar belakangi maka, kata tersebut tetap akan merujuk pada 'lubang pada jarum' dan tidak akan pernah terjadi merujuk pada makna 'mata' sebagai indera penglihatan.

\section{Metode Penelitian}

Penelitian ini menggunakan pendekatan kualitatif dan metode deskriptif karena data penelitian berupa kata, frase, dan bentuk ungkapan lainnya yang masuk ke dalam klasifikasi ungkapan gaya bahasa metafora sebagai data penelitian. Data yang digunakan berjumlah 60 data dan diklasifikasikan ke dalam 6 bentuk klasifikassi. Suber data yang digunakan adalah buku berjudul Kike Wadatsumi no Koe yaitu, buku kumpulan surat wasiat, catatan harian, puisi, dan surat-surat pesan lainnya secara keseluruhan berjumlah 79 surat yang semua ditulis oleh para prajurit Jepang yang mendapat tugas sebagai pilot pelaku 
Kamikaze dimasa perang dunia II. Para pilot adalah para sarjana dan mahasiswa yang mendapat tugas wajib militer dengan usia rata-rata antara 21 sampai 27 tahun. Teknik pengumpulan data yang digunakan mengikuti prosedur jenis penelitian kepustakaan dengan metode deskriptif kualitatif. Data yang sudah terkumpul diidentivikasi untuk diklasifikasikan sesuai jenis dan karakter data. Setelah diklsifikasikan data dianalisis selanjutnya dideskripsikan sesuai kondisi riel data yang melibatkan konteks dan hubungan unsur pembentuk tuturan agar diperoleh makna metafora secara rinci, menyeluruh, dan valid. Dari hasil analisis diperoleh hasil bahwa konsep makna ungkapan metafora dalam buku Kike Wadatsumi no Koe terbentuk didasarkan oleh proses perbandingan akibat persamaan konsep aspek tindakan,konsep aspekkarakter/sifat, kedudukan, keadaan, nilai, gerak, dan fungsi.

\section{B. PEMBAHASAN}

\section{Persamaan KonsepAspek Tindakan}

Surat ini ditulis oleh seorang yang memiliki kelemahan secara fisik, akibat kelemahan tersebut nampaknya menjadi penyebab sikap dan tindakan orang-orang disekitarnya dirasakan memberikan perlakuan berbeda bahkan dirasakan sebagai bentuk tindakan yang merendahkan diri penulis.

6). Sorera no hito wa watashi o fumitsukete saki e saki e susumideru. (K.h106. p.5. b. 2$)^{2}$

(Orang-orang itu menginjakku lalu terus berlalu begitu saja).

Kata /fumitsuketel (menginjak) memiliki makna leksikal apa adanya seperti makna unsur pembentuknya. Tetapi dalam contoh 6) di atas bukan makna leksikal yang digunakan, konsep makna leksikal yaitu, menginjakkan kaki pada tempat yang memiliki posisi lebih rendah atau benda yang lebih kecil sehingga mudah untuk menginjakkan kaki dan terasa aman. Selanjutnya makna ini dipinjam untuk merujuk tindakan yang sebenarnya berbeda tetapi ada konsep semantis yang disejajarkan yaitu, 'posisi yang lebih rendah' konsep ini digunakan sebagai dasar akibat adanya kandungan makna yang sejajar dengan tindakan menghina atau

\footnotetext{
2 p. menunjukkan paragraf dalam halaman tersebut.
} 
meremehkan orang lain. Ketika tindakan menghina maka, orang yang dihina akan selalu ditempatkan pada posisi yang lebih rendah dari pada orang yang menghina. Dari konsep makna dasar /menginjak/ yaitu melakukan tindakan menginjak pada obyek yang dianggap sudah tidak ada manfaatnya, pada tempat yang memiliki posisi lebih rendah, dan tindakan menganggap suatu obyek yang tidak memiliki nilai, konsep ini disejajarkan dengan pandangan orang-orang terhadap penulis surat yang dianggap sudah tidak memperdulikan lagi, jauh meninggalkan dirinya, dan sudah tidak mungkin akan terjangkau oleh kemampuan fisiknya. Kondisi ini hanya diakibatkan oleh kelemahan fisik yang dimiliki oleh penulis, sehingga penulis menganggap tindakan ini sebagai bentuk tindakan yang merendahkan dan menghina diri penulis. Penulis mengungkapkan situasi kejiwaan tersebut tidak secara eksplisit/langsung tetapi, memilih menggunakan bentuk ungkapan Ifumitsukeru/ (menginjak). Gambaran konteks sebagai dasar untuk menentapkan makna metafora ini selengkapanya dapat dilihat (K.h.106. p.2. b.1-3 dan p.5-6). Sedangkan bentuk gaya bahasa metafora lain yang masuk klasifikasi ini adalah, /hansuu no doubutsu/ (binatang memamah biak) (K.h.310.p2.b2-4), /ikigurushii kankinnseikatsul (kehidupan penjara yang menyesakkan nafas) (K.h.215216.p2.b.1-3 dan b.7-10).

\section{Persamaan Konsep Aspek Kedudukan}

7). Gochou kurai wa mouKami sama desu. (K.h.58.p.2.b.8).

(Kalau sudah kopral sudahDewa).

/Gochou/ (kopral) di dalam dunia militer adalah seorang pemimpin yang memiliki tugas mengetuai pasukan prajurit perang. Kedudukan kopral sudah memiliki kekuasaan atas anggota pasukan yang dipimpinnya. Anggota yang berperan sebagai anak buah memiliki kewajiban menurut, mengikuti, dan melaksanakan semua perintah pimpinan yaitu kopral. Konsep ini digunakan sebagai dasar untuk menyamakan gambaran hubungan antara umat/pengikut kepercayaan terhadap Dewa yang dianutnya. Dalam hubungan ini, umat/pengikut melaksanakan semua apa yang diperintahkan oleh Dewa dan sebaliknya, Dewa selaku yang memiliki posisi kedudukan yang tinggi bisa memerintahkan apa saja 
kepada umat/pengikutnya. Keleluasaan, kebebasan, dan kekuatan kewenangan memerintah yang dimiliki oleh Dewa serta sifat kepatuhan, kewajiban untuk patuh, dan keharusan melaksanakan perintah yang dimiliki oleh umat/pengikutnya, membentuk pola pikir terhadap penulis untuk mengaktualisasikan gagasannya atas kondisi yang dialami yaitu gambaran tentang kebesaran dan keleluasaan kekuasaan serta kewenangan yang dimiliki oleh seorang kopral atas prajurit yang menjadi anak buahnya. Kopral menempatkan dirinya pada posisi tertinggi dalam garis komando organisasi kelompoknya tidak ada yang menyamai bahkan melampaui sehingga, kewenangan untuk memberikan komanda terhadap para prajurit yang menjadi anak buah bersifat tidak terbatas. Sebaliknya para prajurit yang menjadi anak buah tidak memiliki kebebasan untuk melakukan pilihan apa lagi penolakan, pelaksanaan terhadap komando perintah kopral bersifat wajib seperti umat/pengikut melaksanakan perintah Dewa yang diyakini. Penolakan terhadap perintah kopral oleh seorang prajurit akan berkonskuensi terhadap datangnya sanksi atau hukuman dari kopral seperti para umat/pengikut yang menolak atau melanggar terhadap perintah Dewa akan berbalik dosa yang akan diterimakan.

Pemaknaan seperti di atas diperkuat dengan digunakan partikel /mou/ (sudah) yang memiliki fungsi semantis selain makna kala waktu juga memaksimalkan makna unsur yang mengikuti sekaligus menyamakan pokok kalimat dengan subyek yang menerangkan. Artinya, kata /kami samal (dewa) yang mengikuti maknanya melebihi makna awalnya dan pokok kalimat /gochoul (kopral) menyejajarkan dengan makna /kami samal (Dewa). Pokok kalimat sebelum mencapai posisi kopral belum memiliki kekuasaan dan kewenangan sebesar kopral, tetapi ketika sudah mencapai posisi kopral kekuasaan dan kewenangannya berubah menjadi setara dengan Dewa. Pada proses ini sebenarnya secara konsep perbandingan sudah terjadi dan menandai penggunaan kata /kami sama/ (Dewa) sebagai pembanding untuk menggantikan kata /gochoul (kopral). Tanpa menyinggung kondisi psikis penulis, nampaknya ada unsur suasana batin lain yang menyertai ketika penulis memilih untuk menggunakan kata /kami sama/ (Dewa) tersebut untuk merujuk pada makna /gochoul (kopral). Untuk mendapatkan gambaran selengkapnya terkait isi surat ini dapat dikonfirmasikan 
dengan teks selengkapnya khusunya yang memiliki konteks tema dengan kutipan 7) di atas dalam buku sumber (K.h.58.p.2.b.5-8).

\section{Persamaan Konsep Aspek Karakter}

8). Jinrui yo, saru no shinrui yo. (K.h.210.p.9.b.5)

(Manusia kan, kerabat kera kan?).

Kata /saru/ (kera) pada contoh 8) oleh penulis disandingkan dengan manusia. Hal ini karena kera dianggap sebagai jenis binatang primata yang memiliki garis kekerabatan satu garis lurus. Kera ditempatkan pada garis kekerabatan tertua yang terus mengalami evolusi hingga mencapai kondisi sempurna sebagai manusia yang ditandai oleh berfungsinya hati nurani dan akal sebagai penciri khusus mahkluk Tuhan yang paling sempurna. Hal ini diperkuat oleh pendapat Soekmono (1973:6-7) menyebutkan, manusia memiliki akal dan dengan akalnya manusia dapat memikirkan dan mengupas masalah-masalah yang dihadapinya, sedangkan kera hanya bergerak mengikuti naluri. Artinya, manusia meskipun dikatakan sebagai hasil proses penyempurnaan tingkat peradaban dari jenis primata, tetapi karena memiliki akal yang menghasilkan aspek intelektual pada diri manusia dan akhirnya mengangkat tingkat peradaban manusia keluar dari tingkat peradaban kelas primata ke posisi yang lebih tinggi. Unsur mental dan intelektual merupakan unsur yang dapat melepaskan kelas manusi dari kelas primata dan menjadi pembeda yang paling ekstrim di antara keduanya. Meskipun kera merupakan jenis primata yang memiliki tingkat kecerdasan paling tinggi, tetapi jenis kera yang hanya bergerak berdasarkan nalurinya saja karena tidak memiliki akal apa lagi intelektual, akhirnya menempatkan dirinya pada posisi di bawah kelas manusia baik dari aspek akal, intelektual, dan hati nurani.

Pembedaan kelas primata kera dari kelas manusia sering memunculkan persepsi yang tidak baik ketika manusia disamakan dengan kera. Manusia yang disejajarkan dengan kera secara tidak langsung menempatkan manusia pada kelas kera, unsur akal dan intelektual yang dimiliki oleh manusia seakan dihilangkan. Seolah-olah memundurkankembali tingkat kemampuan berfikir dan tingkat 
kemampuan merasa dengan hati nurani manusia kepada masa sebelum evolusi. Kemapuan intelektual manusia disamakan hanya setingkat kemampuan berfikir primata kera. Tingkat peradaban primata kera yang hampir tidak mengalami perubahan dan kemajuan sebagai penanda rendahnya kemampuan berpikir dan akal kelompok primata ini jika dibandingkan dengan tingkat kemampuan manusia. Melalui pemahaman seperti ini penggunaan ungkapan /saru no shinrui/ (kerabat kera) bukan semata-mata merujuk kepada kelompok kera tetapi merujuk kepada kelompok orang yang dianggap memiliki kemampuan berpikir dan akal yang rendah dengan tujuan untuk merendahkan kemampuan orang yang dimasud. Penulis melukiskan peperangan yang dilakukan oleh orang-orang bukan didasari tujuan untuk memajukan negara tetapi hanya mencapai kemenangan guna menguasai yang kalah. Tindakan perang dianggap hanya berdasarkan pada ledakan emosi akibat tingkat pemikiran yang dangkal sebagai perwujudan dari pemikiran dan tindakan yang bodoh layaknya tindakan binatang primata kera.

Sebenarnya bentuk ungkapan ini dapat juga diklasifikasikan ke jenis gaya bahasa sindiran, tetapi proses untuk mencapai hingga terbentuk gaya bahasa sindiran harus melalui proses perbandingan sebagai penciri gaya bahasa metafora. Kutipan selengkapnya dapat dilihat (K.h.210.p.6.b.6-10). Sedangkan data lain yang masuk klasifikasi ini ialah, /kemonol (binatang buas), /kikail (mesin) (K.h.7.b.1), lgokoku no onitachil (setan pelindung negara) (K.h47.b.5), lawaiyume/ (mimpi yang pudar) (K.h.150.b.6).

\section{Persamaan Konsep Aspek Keadaan}

\section{9). Ha o kuishibari, jouhoujimu ni ichiihonshou suru tsumori da. (K.h.51.p.1.b.6)}

(Sambil menggigit gigi ${ }^{3}$, aku berniat untuk berjuang di kantor informasi.)

Ungkapan di atas menurut kamus Kokugo Kanyouku (1978: 348) memiliki makna metafora keadaan bersabar meskipun sedang kesal, marah, atau sangat menderita. Sebagai ilustrasi untuk memaknai ungkapan pada 9) di atas, berikut dikutipkan penggalan pernyataan yang mendahului ungkapan tersebut sebagai 
gambaran konteks tema. Kesedihan teman-teman perang, tragedi perang, macammacam telah aku alami, benar-benar menyiksa. Tetapi, sekarang secara diam-diam aku berpikir bahwa, rasanya ini adalah kewajiban sebagai personil kepala bagian pusat (K.h.51.p.1.b.3-4). Kutipan di atas mengisyaratkan kondisi psikis penulis pada saat itu, yang dihadapkan pada dua situasi kejiwaan yang kontradiksi. Di satu pihak harus menahan kesabaran meskipun melihat dan mengalami kondisi yang sangat sulit bahkan kondisi yang bisa mengancam keselamatan dan jiwa dirinya maupun teman-teman seperjuangannya, sisi lain jiwanya tidak ingin tinggal diam dan membiarkan kondisi yang menyiksa terus mengintai kehidupannya. Tetapi, nampaknya penulis lebih memilih untuk menahan kesabaran meskipun dirinya juga harus menahan tekanan jiwanya yang terus berontak untuk tidak membiarkan peristiwa perang terus mengancam kehidupannya. Hal ini digambarkan dengan digunakan bentuk ungkapan /shizuka na omoil (berpikir tenang). Menahan dua kondisi kejiwaan yang bertentangan bukan hal yang mudah. Kondisi semacam ini terlukiskan dalam bentuk ungkapan Iha o kuishibaril (menggigit gigi), artinya pada saat seperti ini, kedua mulut mengatup untuk menahan dan menutupi gigi atas bagian belakang dan gigi bawah bagian belakang yang saling menekan namun demikian tidak mengakibatkan rasa sakit. Kondisi menggigit gigi yang tidak menimbulkan rasa sakit digambarkan sebagai peralihan kondisi marah, benci, tetapi rasa marah dan benci tersebut tidak terluapkan. Rasa marah dan benci hanya ditahan dengan cara menggigitkan gigi menahan atas kondisi yang tidak diinginkan. Kemarahan yang tidak diperlihatkan kepada orang lain menggambarkan kekuatan, ketabahan, dan kesabaran seseorang dalam menghadapi serta melalui berbagai bentuk kesulitan. Bentuk ungkapan yang memiliki karakteristik sematis seperti ini ialah, /ikeru shikabane no seikatsu/ (kehidupannya mayat hidup) (K.h.67.b.8), Ime o dashitel (tumbuh tunas) (K.h.156.b.5), /butail (panggung) (K.h.222.p.1.b.4), Inigai kajitsu/ (buah pahit) (K.h.282.p.1.b.1). 


\section{Persamaan Konsep Aspek Nilai}

\section{0). Subete o hitei shi, kyomu no seikatsu shisou ni narietara donna ni yukai darou. (K.h.104.b.9). \\ (Bagaimana bisa menikmati jika, aku menolak semuanya dan pikiran hidup menjadi kosong).}

Makna leksikal /kyomu no seikatsu shisou/ (pikiran hidup kosong) pada contoh 10) di atas digunakan untuk mewakili ungkapan yang merujuk informasi (ideologi kehidupan yang tidak cerdas). Kondisi /kosong/ secara konseptual tidak ada sesuatu apapun. Kondisi ini dihubungkan dengan kata/pikiran/ yang secara logikan berfungsi sebagai pengendali ide dan gagasan manusia. Pikiran yang kosong dilogikakan sebagai bentuk tidak berfungsinya pikiran sehingga tidak mampu menghasilkan suatu ide atau gagasan di dalam berkehidupan. Penulis nampaknya ingin memberikan gambaran terkait teman dan orang-orang di sekitarnya yang mayoritas dianggap tidak memiliki pemikiran untuk membangun suatu kehidupan yang lebih baik, lebih terhormat dan lebih berwibawa. Hal ini diperkuat oleh pernyataan penulis dalam surat yang sama seperti pada penggalan kutipan berikut, 'kalaupun aku berbicara dengan orang yang cara berpikirnya sederhana, toh pada akhirnya tidak ada lagi pembicaraan kecuali pembicaraan yang bertema mabuk-mabukan' (K.h.104.p.1.b.6). Penulis menunjukkan rasa ketidak puasan atau kekecewaan terhadap sikap dan cara berpikir teman-temannya yang dianggap tidak memiliki gagasan dan pemikiran yang lebih beik untuk membangun kehidupan berbangsa. Pemikiran yang diawali dari pribadioleh setiap individu dianggap sesuatu yang berkeharusan karena, berawal dari kemampuan berpikir pribadi inilah suatu kehidupan berbangsa yang melibatkan banyak orang akan bisa terbentuk. Konsep ide atau gagasan pada teks di atas lebih merujuk kepada suatu konsep ideologi, terutamanya ideologi yang dikaitkan dengan kehidupan bangsa yang bermartabat khususnya bangsa Asia Timur.Tetapi nampaknya harapan penulis tidak dengan mudah dapat tercapai setelah melihat realitas kemampuan berpikir teman-teman dan orang-orang disekitarnya tidak lebih dari suatu keterbiasaan berpikir yang lebih bersifat meneruskan kebiasaan para senior dan bahkan para leluhurnya. Gebrakan pemikiran yang mampu 
membawa kebangkitan gerakan untuk membangun bangsa yang bermartabat tidak banyak dapat dijumpai. Nilai pemikiran yang dianggapnya sebagai hasil pemikiran orang-orang yang tidak cerdas, ide dan gagasan yang datar dan tidak akan menghasilkan bentuk kehidupan baru, hanya ingin menaklukkan negara lain, menandai setiap simbul-simbil komunis adalah sebagai tanda kurang cerdasnya bagi semua pemiliknya. Untuk dapat membuktikan konsep pemaknaan metafora ini dapat ditelusuri pada teks selengkapnya (K.h.104.p1-2.).

\section{Persamaan Konsep Aspek Gerak}

11). Unmei no sharin wa mawarihajimete sono tomarutokoro o shiranai. (K.h.205.p.2b.2).

(Roda nasib mulai berputar dan tidak tahu tempat berhentinya).

Kata /sharin/ (roda) memiliki standar gerak yang wajar yaitu berputar. Dengan berputar maka akan merubah posisi permukaan roda, yang semula permukaan di bawah dapat berubah menempati posisi di samping maupun posisi atas dan bahkan kembali lagi ke posisi semula. Ketika kata /sharin/ (roda) ini disandingkan dengan kata /unmeil (nasib), aspek kesamaan yang mendasari diantara keduanya menjadi memungkinkan untuk dipertukarkan penggunaannya ialah, perubahan posisi yang tidak dapat diprediksi akibat perputaran pada roda dan perubahan keadaan/kondisi yang tidak dapat diprediksi oleh siapapun akibat perubahan yang dikehendaki oleh Yang Maha Kuasa sebagai pemilik kehidupan dan penentu nasib setiap manusia. Kedua aspek ini disejajarkan yang dianggap mampu mengikat keduanya untuk membangun hubungan perbandingan unasur /sharin/ (roda) berperan sebagai pembanding dan /unmei/ (nasib) berfungsi sebagai yang dibandingkan. Akibat hubungan ini, kata /sharin/ (roda) menjadi unsur pembentuk struktur lahir/luar guna menggambarkan kondisi dan perubahan nasib yang dimiliki oleh setiap manusia termasuk penulis surat ini. Penulis nampak sekali memiliki kesadaran akan nasib manusia yang selalu berubah layaknya perubahan posisi permukaan roda yang selalu berubah akibat perputaran. Tidak ada manusia yang dapat memprediksi nasibnya sendiri maupun nasib orang lain, seperti kita tidak akan bisa menebak dimana akan berhenti bagian permukaan 
tertentu pada roda yang berputar. Penulis surat menyadari sekali akan nasibnya sendiri maupun teman-teman yang sama-sama sedang menjalankan tugas dalam medan perang, menyadari nasib akan tugasnya sebagai penerbang yang harus mengawaki pesawat tempur untuk melancarkan serangan ke kapal perang induk lawan khusunya kapal perang Amerika. Tugas ini juga dianggapnya tidak lepas dari nasib karena, penulis sendiri khususnya dan para prajurit yang mendapatkan tugas untuk menjadi pilot pesawat tempur yang memiliki tugas utama melancarkan serangan dengan menabrakkan pesawat yang diawaki ke kepal perang lawan tentunya tidak pernah memprediksikan atau tidak pernah merencanakan hal tersebut akan terjadi. Tugas yang dijalani semata-mata akibat nasib melalui komando yang diberikan oleh para komandan atau pimpinan mereka masing-masing. Bentuk ungkapan lain yang memiliki hubungan konsep semantis jenis ini yaitu, /murasaki no kemuri no mai/ (tarian asap ungu) (K.h297.p.2. Inoue Hisashi).

\section{Persamaan Konsep Aspek Fungsi}

12). Jibun no risou no ippashi o uketa seishitsu wa jibun no risou ni mukatteomoi you ni tsumakyouiku ni douka sarete kureta taisetsu na wa ga kokoro no taiyou desu. (K.h53.b.3)

(Salah satu sifat yang ada dalam pikiranku adalah, matahari hatiku, dimana aku yang diutamakan dalam tuntunan istriku, seperti menghadap ke pikiranku sendiri).

Unsur kata /taiyou/ (matahari) adalah salah satu jenis gugus dalam tata surya yang memiliki cahaya, berfungsi sebagai pusat berputarnya planet-planet anggota tata surya sekaligus sebagai pusat panas/energi planet-planet yang mengelilingi. Komponen cahaya yang berperan sebagai penerang dan komponen panas yang berperan sebagai sumber energi kekuatan menjadi kendali utama untuk membentuk ungkapan metafora ketika unsur kata /taiyou/ (matahari) dirangkai dengan kata /kokoro/ (hati). Dua komponen utama yaitu cahaya dan energi yang dimiliki matahari digunakan sebagai pembanding untuk menggambarkan suasana hati penulis disaat mendapat tuntunan, bimbingan, dan nasehat dari /tsuma/ (istri). Bimbingan dan nasehat istri dilukiskan mampu menerangi suasana hati, 
membangkitkan kekuatan dan semangat kembali disaat penulis merasakan suasana hatinya mulai padam, lesu hilang semangat, dan disaat kekuatan hatinya mulai rapuh akibat kejenuhan dalam masa tugas militer. Penulis menyajikan gambaran kekuatan dan kebesaran yang dimiliki oleh istrinya layaknya cahaya dan energi kekuatan yang dimiliki oleh matahari. Pentingnya vigur istri yang mampu memberikan pencerahan, inspirasi, sumber kekuatan, dan sember segala gagasan layak ditempatkan sebagai matahari di dalam setiap hati kehidupan penulis. Munculnya kata /taiyou/ (matahari) sebenarnya lebih untuk menunjukkan besarnya peranan seorang istri bagi seorang suami khususnya penulis, khususnya disaat suami mengalami penurunan kondisi mental/psikis. Penulis nampak nampaknya juga hendak menyampaikan tentang gambaran seorang istri yang mampu berperan sebagai sumber inspirasi, kekuatan dan pencerahan, dengan sendirinya akan selalu ada dan menyatu dalam hati dan setiap kehidupan seorang suami. Bentuk ungkapan metafora lain yang dapat diklasifikasikan ke dalam jenis ini adalah, /kumo no su/ (sarang laba-laba) (K.h.148.b.3), Igin no shouhakol (kotak besi) (K.h.151.p.4.b.1\&4), /sute ishil (batu buangan) (K.h.298.P.3.b.5).

\section{PENUTUP}

Gaya bahasa memiliki peranan yang sangat penting dalam tindak komunikasi karena penggunaannya turut menentukan tingkat efektifitas dalam rangka mencapai tujuan komunikasi. Salah satunya gaya bahasa metafora adalah termasuk jenis yang memiliki frekuensi pemakaian yang cukup tinggi khususnya dalam bahasa buku Kike Wadatsumi no Koe. Gaya bahasa metafora dipilih oleh para penulis sebagai sarana untuk mencurahkan suasana batin dan psikis untuk menandai setiap pengalaman dan gagasan selama dalam tugas militer tepatnya disaat-saat menjelang pelaksanaan tugas penyerbuan dengan pesawat tempur yang dikenal dengan peristiwa Kamikaze. Melalui proses pembandingan untuk mengemas makna dan informasi tuturan, pemindahan makna dari pembanding ke yang diperbandingkan membantu penyampaian kepada mitra tutur yaitu pembaca. Pemindahan makna terjadi dengan didasari oleh beberapa kesamaan konsep yaitu, kesamaan konsep aspek tindakan, aspek kedudukan, aspek karakter, aspek 
keadaan, aspek nilai, aspek gerak, dan aspek fungsi. Masing-masing aspek berperan sebagai dasar terbentuknya ungkapan gaya bahasa metafora dengan menggunakan unsur pembanding sebagai bentuk ungkapan real sedang unsur yang dibandingkan berfungsi sebagai rujukan.

\section{DAFTAR PUSTAKA}

Djajasudarma, T. Fatimah. 1999. Semantik I (Pengantar Arah Ilmu Makna). Bandung: Rafika Aditama.

Keraf, Gorys. 2010. Diksi dan Gaya Bahasa. Jakarta: Teruna Grafika.

Nakamura, Akira. 1985. Hiyu Hyogen Jiten. Japan: Kadokawa Shoten.

Parera, J.D. 2004. Teori Semantik Edisi Kedua. Jakarta. Erlangga.

Ratna, Nyoman Kutha. 2009. Stilistika: Kajian Puitika Bahasa, Sastra dan Budaya. Yogyakarta: Pustaka Pelajar.

Seto, Kenichi. 1997. Ninshiki no Retorikku. Japan: Kaimeisha.

Seto, Kenichi. 1995. Kuukan no Retorikku. Japan: Kaimeisha.

Shogakukan. 1988. Kokugo Daijiten. Tokyo: Shogakukan.

Soekmono, R. 1973. Sejarah Kebudayaan Indonesia 1. Yogyakarta: Kanisius.

Subandi. 2000. "Terjadinya Makna Idiomatikal Kata Majemuk Bahasa Jepang Ditinjau dari Konsep Metafora". Verba. Vol. 8, No. 2. Surabaya: FBS Unesa.

Sumardjo, Jakob dan K.M, Saini. 1986. Apresiasi Kesusastraan. Jakarta: PT Gramedia.

Sutedi, Dedi. 2008. Dasar-Dasar Linguistik Jepang. Bandung: Humaniora Utama Press.

Takiura, Shizuo. 1988. Phaenomenologica Metafa Genshougaku. Japan: Sekaishoin.

Tarigan, Henri Guntur. 1990. Pengajaran Semantik. Bandung: Angkasa.

Ungerer, Friedrich dan Hans-Jörg. 1996. Ninchigengogaku Nyumon (alih bahasa oleh Ikegami Yoshihiko). Tokyo: Taishukan Publishing Company.

Yamanashi, Masaaki. 1988. Hiyu to Rikai. Japan: Tokyo Daigaku. 